\title{
Phospholipid-Metabolizing Enzyme A-C1
}

National Cancer Institute

\section{Source}

National Cancer Institute. Phospholipid-Metabolizing Enzyme A-C1. NCI Thesaurus. Code C153058.

Phospholipid-metabolizing enzyme A-C1 (168 aa, 19 kDa) is encoded by the human HRASLS gene. This protein plays a role in phosphate removal from and acetylation of lipids. 